\title{
IDENTIFIKASI VARIABEL PENGHAMBAT DALAM DISTRIBUSI SEMEN DI KOTA TARAKAN
}

\section{IDENTIFICATION OF INHIBITING VARIABLES IN DISTRIBUTION OF CEMENT IN TARAKAN CITY}

\author{
Eko Prihartanto ${ }^{1)}$ \\ 1) Jurusan Teknik Sipil, Fakultas Teknik, Universitas Borneo Tarakan \\ Email: ${ }^{1}$ eko_prihartanto@borneo.ac.id
}

\begin{abstract}
ABSTRAK
Penelitian ini bertujuan untuk mengetahui proses rantai pasok material semen dan meninjau pihak-pihak yang terlibat didalamnya dan untuk mengetahui rantai pasok material semen pada proyek kontruksi di Kota Tarakan. Jenis penelitian ini merupakan penelitian survey yang dilakukan dengan cara membagikan kuesioner kepada responden yang berkaitan dengan objek penelitian pada proyek konstruksi yaitu para kontraktor yang sedang menjalankan proyek konstruksi di Kota Tarakan. Hasil data yang diperoleh berdasarkan skor yang dihasilkan dari kuesioner dengan cara perhitungan yaitu skor yang diperoleh dari responden dibagi dengan jumlah responden. Hasil penelitian ini menunjukan Proses pertama yang dilakukan dalam rantai pasok material semen di kota Tarakan yaitu melalui logistik yang melakukan pemesanan semen melalui SMS ataupun telepon pada pihak pengecer/supplier yaitu kepada costumer service. Selanjutnya pihak kontraktor melakukan proses pembayaran dengan cara transfer. Proses terakhir yaitu pengiriman semen dari distributor kepada pengecer/supplier kemudian dikirim ke proyek konstruksi. Adapun pihak yang ikut terlibat dalam proses rantai pasok material semen di Kota Tarakan yaitu pabrik, distributor, pengecer/supplier, logistik proyek, bagian keuangan, dan pekerja gudang pada proyek konstruksi. Selanjutnya manajemen rantai pasok material semen pada proyek kontruksi di Kota Tarakan termasuk dalam kategori sangat baik dapat dilihat pada presentase indikator kualitas produk semen yang digunakan sesuai permintaan tergolong dalam kategori sangat baik (nilai 4,27), indikator perencanaan pemilihan produk semen termasuk dalam kategori sangat baik (nilai 4,32), dan indikator Pengolahan dana untuk pembelian produk material tergolong dalam kategori sangat baik (nilai 4,27). Dengan demikian diharapkan para kontraktor proyek kontruksi yang ada di Kota Tarakan dapat dipertahankan dan dapat ditingkatkan.
\end{abstract}

\section{Kata Kunci: Logistik, Rantai pasok, Semen}

\begin{abstract}
This study aims to determine the supply chain process of cement material and review the parties involved in it and to determine the supply chain of cement material in construction projects in Tarakan City. This type of research is a survey research conducted by distributing questionnaires to respondents related to the object of research on construction projects, namely contractors who are running construction projects in Tarakan City. The results of the data obtained are based on the scores generated from the questionnaire by calculating the score obtained from the respondents divided by the number of respondents. The results of this study show that the first process carried out in the cement material supply chain in the
\end{abstract}


city of Tarakan is through logistics which places an order for cement via SMS or telephone to the retailer/supplier, namely to customer service. The contractor then proceeds with the payment process by transfer. The last process is the delivery of cement from the distributor to the retailer/supplier then sent to the construction project. The parties involved in the cement material supply chain process in Tarakan City are factories, distributors, retailers/suppliers, project logistics, finance, and warehouse workers on construction projects. Furthermore, the supply chain management of cement materials in construction projects in Tarakan City is included in the very good category, it can be seen in the percentage of quality indicators of cement products used on demand which are in the very good category (value 4.27), indicators for planning the selection of cement products are included in the very good category. good (value 4.32), and the indicator of Fund processing for the purchase of material products is in the very good category (score 4.27). Thus, it is hoped that the construction project contractors in Tarakan City can be maintained and can be improved.

\section{Keywords: Cement, Logistics, Supply chain}

\section{PENDAHULUAN}

Rantai pasok adalah konsep yang awalnya berasal dari industri manufaktur. Industri ini merupakan pola distribusi produk yang digunakan untuk menggantikan pola tradisional. Pola baru ini terkait dengan aktivitas distribusi, jadwal produksi dan logistik (Ulfah, 2015). Rantai pasok menghubungkan pemasok yang terkait satu sama lain untuk menghasilkan bahan yang dibutuhkan karena adanya permintaan akan suatu produk. Menurut Pujawan (2017), dalam rantai pasok terdapat keterkaitan berbagai pihak yaitu hubungan dari hulu (upstream) sampai ke hilir (downstream), untuk mendapatkan barang dan jasa yang di butuhkan.

Keterlibatan berbagai pihak tersebut dengan keahlian dan tujuan yang berbeda menjadikan pekerjaan konstruksi ini terbagi dalam beberapa paket pekerjaan yang dilaksanakan oleh berbagai pihak yang berbeda sehingga sering terjadi beberapa permasalahan. Permasalahan yang sering muncul terkait rantai pasok yaitu biaya logistik yang tinggi dan keterlambatan waktu pengiriman (Sherlywati, 2017). Untuk menghindari beberapa permasalahan tersebut perlu adanya manajemen rantai pasok.

Manajemen rantai pasok adalah suatu metode atau pendekatan yang digunakan untuk mengelola aliran produk, informasi dan uang secara terintegrasi yang melibatkan beberapa pihak seperti pemasok, pabrik, pelaku kegiatan distribusi dan jasa logistik. Prinsip yang digunakan dalam manajemen rantai pasok adalah transparansi informasi dan kolaborasi, baik antar fungsi di dalam perusahaan maupun pihak di luar perusahaan di sepanjang rantai pasok. Kegiatan manajemen rantai pasok meliputi pengembangan produk, pengadaan material dan komponen, perencanaan produksi dan pengendalian persediaan, produksi, distribusi dan penanganan pengembalian (Pujawan, 2017).

Kota Tarakan merupakan kota yang terletak di Provinsi Kalimantan Utara, kota ini dijuluki sebagai kota transit. Oleh karena itu dituntut peningkatan pada sektor pembangunan konstruksi sarana maupun prasarana demi kelancaran berbagai aktivitas antar pulau yang berada di Provinsi Kalimantan Utara. Setiap kegiatan proyek pembangunan yang dilaksanakan oleh kontraktor pastilah memerlukan pasokan material. Menurut Brostito (2016) ada beberapa hal yang mempengaruhi rantai pasok material konstruksi di Kota Tarakan yaitu jarak antar lokasi proyek dan pemasok, kualitas bahan logistik, jenis alat angkut yang biasa dipakai pada proses pengiriman material, 
JURNAL BORNEO SAINTEK

Volume 3, Nomor 2, Oktober 2020

e-ISSN 2599-3313

P-ISSN 2615-434X

jumlah staf yang kurang sehingga kontrol terhadap pemasok kurang diperhatikan, kurangnya stok material pada pemasok dan kecelakaan pada saat pengiriman material. Hal tersebut yang menyebabkan terhambatnya pengerjaan proyek konstruksi di Kota Tarakan.

Penelitian ini bertujuan untuk megetahui proses rantai pasok material semen dan meninjau pihak-pihak yang terlibat didalamnya serta untuk mengetahui manajemen rantai pasok material semen pada proyek konstruksi di Kota Tarakan.

\section{METODE PENELITIAN}

a) Jenis Penelitian

Jenis penelitian ini adalah penelitian survey yang dilakukan dengan menyebarkan kuesioner kepada responden yang berkaitan dengan objek penelitian pada suatu proyek konstruksi di Kota Tarakan. Penelitian ini bertujuan untuk mengetahui proses rantai pasok material semen dan meninjau pihak-pihak yang terlibat didalamnya serta untuk mengetahui manajemen rantai pasok material semen pada proyek konstruksi di Kota Tarakan. Hasil analisis menggunakan pendekatan deskriptif kualitatif untuk melihat pola hubungan yang terjadi.

\section{b) Tempat dan Waktu Penelitian}

Penelitian ini dilakukan pada proyek konstruksi yang berada di Kota Tarakan dan dengan catatan sedang dalam pengerjaan. Penelitian ini dilaksanakan pada bulan Agustus-September 2020.

\section{c) Objek Penelitian}

Objek dalam penelitian ini yaitu responden para kontaktor yang sedang menjalankan proyek konstruksi di Kota Tarakan. Responden yang terlibat dalam pengisisan kuesioner yaitu project manager, site manager, site engineer, logistic dan pelaksanaan.

d) Uji Kuesioner

1. Uji Validasi
Available online at www.jurnal.borneo.ac.id Halaman 93-99

Dalam penelitian ini digunakan perangkat lunak SPSS untuk uji validitas. Teknik pengujian digunakan untuk menguji validitas dengan mengkorelasikan skor tiap item dengan skor total. Skor total adalah jumlah dari semua item. Jika $r$ hitung $\geq r$ tabel maka angket valid. Rumus Korelasi Product Moment untuk mengukur validitas adalah sebagai berikut:

$$
r_{x y}=\frac{N \sum X Y-\left(\sum X\right)\left(\sum Y\right)}{\sqrt{\left[\left(N \sum X^{2}-\left(\sum X\right)^{2}\right]\left[N \sum X^{2}-\left(\sum Y\right)^{2}\right]\right.}}
$$

Dimana :

$r_{x y} \quad=$ koefisiesn korelasi yang dicari

$\sum X Y \quad=$ jumlah varian antara variabel $\mathrm{x}$

$\sum X^{2} \quad$ dan $\mathrm{y}$ jumlah dari kuadrat nilai $\mathrm{x}$

$\sum Y^{2}=$ jumlah dari kuadrat nilai $\mathrm{y}$

$\left(\sum X\right)^{2}=$ jumlah nilai $\mathrm{x}$ kemudian dikuadratkan

$\left(\sum Y\right)^{2}=$ jumlah nilai y kemudian dikuadratkan

$N \quad=$ jumlah responden

Jika $r$ hitung $\geq r$ tabel maka butir soal tersebut valid.

2. Uji Reliabilitas

Kuesioner yang reliabel adalah kuesioner yang apabila digunakan beberapa kali untuk mengukur objek yang sama akan menghasilkan data yang sama. Untuk menguji reliabilitas menggunakan software SPSS 22 . Rumus yang digunakan adalah rumus Cronbach's Alpha (a) sebagai berikut:

$$
r 11=\left[\frac{n}{n-1}\right]\left[1-\frac{\sum s_{t}^{2}}{s_{t}^{2}}\right]
$$

Keterangan :

$r 11=$ realiabilitas tes secara keseluruhan

$n=$ banyak butir soal

$\sum s_{t}{ }^{2}=$ jumlah varians skor tiap item

$s_{t}{ }^{2} \quad=$ varians skor total

Tahapan dalam pengujian reliabilitas adalah dengan menentukan nilai $t$ tabel dengan tingkat signifikan 95\% $(a=0,05)$ dengan kriteria pengambilan keputusan sebagai berikut. Jika $\mathrm{t}$ hitung $\geq \mathrm{t}$ tabel 
JURNAL BORNEO SAINTEK

Volume 3, Nomor 2, Oktober 2020

e-ISSN 2599-3313

P-ISSN 2615-434X

maka item tersebut reliabel. Jika t hitung $\leq$ $\mathrm{t}$ tabel maka item tersebut tidak reliabel.

e) Metode Analisis Data

1. Analisis Deskriptif

Menurut Sugiyono (2016) analisis deskriptif adalah statistik yang digunakan untuk menganalisis data dengan mendeskripsikan data yang telah dikumpulkan, tanpa bermaksud membuat kesimpulan yang berlaku untuk umum. Metode ini bertujuan untuk mendeskripsikan proses rantai pasok semen dan pihak-pihak yang terlibat di dalamnya.

2. Analisis Hitungan Mean (rata-rata)
Available online at www.jurnal.borneo.ac.id Halaman 93-99

Mean didefinisikan sebagai jumlah nilai dibagi oleh banyak subyek. Microsoft Excel digunakan untuk membantu perhitungan agar lebih mudah dan akurat. mean dapat di rumuskan sebagai berikut :

$$
\begin{array}{ll} 
& \\
\text { Keterangan : } & \mathrm{Xi} / \mathrm{n} \\
\mathrm{X} & \text { : Nilai rata-rata } \\
\mathrm{xi} & \text { : Jumlah skor yang dihasilkan } \\
\mathrm{n} & \text { : Jumlah data kuesioner }
\end{array}
$$

Selanjutnya mengkonversi skor rata-rata yang diperoleh berdasarkan kriteria penilaian menurut Widyoko (2009), sebagai berikut :

Tabel 1. Kriteria penilaian

\begin{tabular}{cl}
\hline Interval & Kriteria \\
\hline$\overline{\boldsymbol{x}}>\mathbf{4 , 2}$ & Sangat Baik \\
$\mathbf{3 , 4}<\overline{\boldsymbol{x}} \leq \mathbf{4 , 2}$ & Baik \\
$\mathbf{2 , 6}<\overline{\boldsymbol{x}} \leq \mathbf{3 , 4}$ & Cukup \\
$\mathbf{1 , 8}<\overline{\mathbf{x}} \leq \mathbf{2 , 6}$ & Kurang Baik \\
$\overline{\boldsymbol{x}} \leq \mathbf{1 , 8}$ & Tidak Baik \\
\hline
\end{tabular}

Sumber : Widyoko (2009)

\section{HASIL DAN PEMBAHASAN}

1. Rantai Pasok Semen Proyek Konstruksi Kota Tarakan

Berdasarkan hasil dari kuesioner yang telah dibagikan ke lima proyek konstruksi yang ada di Kota Tarakan, dan responden diberikan tujuh belas pertanyaan mengenai proses rantai pasok material semen dan pihak mana saja yang ikut serta dalam preoses pemesanan material semen. Setelah itu hasil dari jawaban para responden di proses ke dalam presentase (\%) dan hasilnya ada di dalam tabel.

\section{Tabel 2. Aliran Produk Material Semen pada Manajemen Rantai Pasok}

\begin{tabular}{llcc} 
No & \multicolumn{1}{c}{ Aliran Produk Material Semen } & Mean & Skala Penilaian \\
\hline $\mathbf{1}$ & Kelancaran pengiriman semen & 4,00 & Baik \\
$\mathbf{2}$ & Penanganan semen pada saat tiba di proyek & 4,00 & Baik \\
$\mathbf{3}$ & Bagian gudang penyimpanan & 4,27 & Sangat Baik \\
$\mathbf{4}$ & Pencatatan semen yang keluar masuk & 4,18 & Baik \\
& gudang & & \\
$\mathbf{5}$ & Tata letak gudang dan penentuan ruang & 4,00 & Baik \\
$\mathbf{6}$ & Sistem distribusi semen & 4,00 & Baik
\end{tabular}


7 Kecukupan semen pada saat pengadaan

4,18 Baik material

8 Pengeluaran produk semen yang digunakan

4,18

Baik sesuai catatan

9 Kualitas produk semen yang digunakan

4,27 Sangat sesuai permintaan

Baik

10 Penanganan khusus dalam hal

4,27

'Sangat keterlambatan produk semen

Baik

Tabel 3. Aliran Informasi Material Semen pada Manajemen Rantai Pasok

\begin{tabular}{|c|c|c|c|}
\hline No & Aliran Informasi Material Semen & Mean & Skala Penilaian \\
\hline & Penjadwalan pembelian semen & 3,86 & Baik \\
\hline 2 & $\begin{array}{l}\text { Koordinasi pihal owner dalam } \\
\text { pelaksanaan proyek }\end{array}$ & 4,14 & Baik \\
\hline 3 & $\begin{array}{l}\text { Komunikasi kendala selama } \\
\text { pelaksanaan proyek }\end{array}$ & 3,91 & Baik \\
\hline 4 & $\begin{array}{l}\text { Komunikasi untuk pengadaan dan } \\
\text { perubahan harga semen }\end{array}$ & 4,05 & Baik \\
\hline 5 & $\begin{array}{l}\text { Komunikasi saat terjadi perubahan } \\
\text { design }\end{array}$ & 3,73 & Baik \\
\hline 6 & $\begin{array}{l}\text { Komunikasi dengan pihak } \\
\text { Pemasok }\end{array}$ & 3,86 & Baik \\
\hline 7 & Kinerja pemasok semen & 3,95 & Baik \\
\hline 8 & $\begin{array}{l}\text { Pemasok memberi informasi terbaru } \\
\text { tentang semen }\end{array}$ & 3,73 & Baik \\
\hline 9 & $\begin{array}{l}\text { Merek semen yang ditawarkan } \\
\text { sangat bagus }\end{array}$ & 4,14 & Baik \\
\hline 10 & $\begin{array}{l}\text { Perencanaan pemilihan produk } \\
\text { semen }\end{array}$ & 4,32 & $\begin{array}{l}\text { Sangat } \\
\text { Baik }\end{array}$ \\
\hline 11 & $\begin{array}{l}\text { Informasi waktu yang diperlukan } \\
\text { dalam pengiriman semen dari pihak } \\
\text { pemasok }\end{array}$ & 4,00 & Baik \\
\hline
\end{tabular}

Tabel 4. Aliran Keuangan Material Semen pada Manajemen Rantai Pasok 


\section{No Aliran Keuangan Material Semen Mean Skala Penilaian}

\begin{tabular}{|c|c|c|c|}
\hline 1 & $\begin{array}{c}\text { Kelancaran pembayaran pekerja oleh } \\
\text { pihak owner }\end{array}$ & 3,91 & Baik \\
\hline 2 & Kelancaran arus dana proyek & 3,77 & Baik \\
\hline 3 & $\begin{array}{c}\text { Penetapan harga dan kesepakatan } \\
\text { pembayaran }\end{array}$ & 3,77 & Baik \\
\hline 4 & $\begin{array}{c}\text { Modal yang cukup untuk memulai } \\
\text { plaksanaan proyek }\end{array}$ & 4,18 & Baik \\
\hline 5 & $\begin{array}{c}\text { Waktu pembayaran kepada pemasok } \\
\text { tepat waktu }\end{array}$ & 4,09 & Baik \\
\hline 6 & $\begin{array}{c}\text { Pembayaran secara teratur kepada } \\
\text { pemasok }\end{array}$ & 4,00 & Baik \\
\hline 7 & $\begin{array}{c}\text { Pengolahan dana untuk pembelian } \\
\text { produk material }\end{array}$ & 4,27 & $\begin{array}{l}\text { Sangat } \\
\text { Baik }\end{array}$ \\
\hline
\end{tabular}

\section{KESIMPULAN}

Beberapa pihak yang ikut terlibat dalam proses rantai pasok material semen di Kota Tarakan yaitu pabrik, distributor, pengecer/supplier, logistik proyek, bagian keuangan, dan pekerja gudang pada proyek konstruksi. Proses pertama yang dilakukan dalam rantai pasok material semen di kota Tarakan yaitu melalui logistik yang melakukan pemesanan semen melalui SMS ataupun telepon pada pihak pengecer/supplier yaitu kepada costumer service. Selanjutnya pihak kontraktor melakukan proses pembayaran dengan cara transfer. Proses terakhir yaitu pengiriman semen dari distributor kepada pengecer/supplier kemudian dikirim ke proyek konstruksi. Setelah tiba semen yang telah datang dicatat tanggal penerimaan dan disimpan di gudang penyimpanan oleh pekerja bagian gudang. Aliran dalam manajeman rantai pasok terbagi menjadi tiga yaitu aliran produk, aliran informasi, dan aliran keuangan. Dengan menggunakan analisis mean dengan nilai maksimum mean adalah lima (5), maka dapat diambil kesimpulan bahwa aliran produk material semen dengan kualitas produk semen yang digunakan sesuai permintaan yaitu dengan mean 4,27 termasuk dalam katagori sangat baik, aliran informasi material semen dengan perencanaan pemilihan produk semen yaitu dengan mean 4,32 termasuk dalam kategori sangat baik, dan aliran keuangan material semen dengan pengolahan dana untuk pembelian produk material yaitu mean 4,27 tergolong dalam kategori sangat baik.

\section{UCAPAN TERIMA KASIH}

Peneliti mengucapkan terima kasih atas bantuan pemerintah melalui Kementerian Pendidikan, Kebudayaan, Riset, dak Teknologi melalui Universitas Borneo Tarakan sehingga penelitian yang berjudul "Identifikasi Variabel Penghambat Dalam Distribusi Semen Di Kota Tarakan" yang dibiayai dengan skema Dana DIPA dapat terselesaikan. Semoga penelitian ini dapat berguna bagi kemajuan bangsa Indonesia.

\section{DAFTAR PUSTAKA}

Brostito, Abi D (2016). Identifikasi Rantai Pasok Material Konstruksi Pada Proyek Konstruksi di Kota Tarakan.

Pujawan, I nyoman. 2017. Supply Chain Management. Edisi ketiga. Yogyakarta: ANDI. 
JURNAL BORNEO SAINTEK

Volume 3, Nomor 2, Oktober 2020

e-ISSN 2599-3313

P-ISSN 2615-434X

Sherlywati.2017. Urgensi Penelitian Manajemen Rantai Pasok: Pemetaan Isu, Objek, dan Metodologi. Vol 17, Nomor 2, pp 147-162.

Sugiyono. 2016 .Metode Penelitian: Kuantitatif, Kualitatif, dan R\&D. Bandung: Alfabeta.

Ulfah, dkk. 2015. Analisis dan Perbaikan Manajemen Resiko Rantai Pasok
Available online at www.jurnal.borneo.ac.id Halaman 93-99

Gula Rafin Asi dengan Pendekatan House of Risk. Jurnal Teknologi Industri Pertanian 26 (1):87103(2016).

Widyoko L. 2009.Pengaruh Sifat Kimia Terhadap Unjuk Kerja Mortar. Jurnal Teknik Sipil UBL. Vol 1. No.1 Oktober 2010. 